\title{
The role of ethnicity in adolescent friendships.
}

\section{A case study with 3 Hungarian secondary school classes with different ethnic composition}

Hanna Kónya ${ }^{1}$

Visiting Postdoc fellow at Universitat Autonoma de Barcelona, GRAFO - Anthropology and Fundamental Oriented Research Group hanna.konya@uni-corvinus.hu

$\begin{array}{ll}\text { (c) }(i) & \text { Received: 01/06/18 } \\ & \text { Accepted: 06/06/18 } \\ & \text { Published: 08/06/18 }\end{array}$

\section{Resumen}

Las teorías de contacto sugieren que vivir en un entorno étnicamente mixto conduce a una mayor tolerancia hacia las minorías, mientras que las teorías de amenazas étnicas muestran la menor amenaza, en entornos con solo un pequeño índice de minorías. Los adolescentes se segregan por muchas características, les gustan algunos y les desagradan por su popularidad, riqueza, frescura, actitudes hacia los deportes o el aprendizaje, etc. Al encontrar el impacto de la etnicidad, comparamos los cambios en la red de amistad observados en tres clases secundarias en Hungría: una con minoría extrema, una clase étnicamente equilibrada y una clase étnicamente homogénea. Los estudios de casos presentados muestran las diferencias entre las clases con respecto a los vínculos de amistad y las estructuras de red también. Estas diferencias sugieren que la composición étnica de las clases se correlaciona con los lazos de amistad, sin embargo, si estas diferencias observadas se deben a la etnicidad, se requiere una metodología que controle todas las demás variables excepto etnia, lo que permite un grupo de control verdaderamente objetivo.

Palabras clave: Segregación, etnia, adolescentes, amistad, evolución de la red

\begin{abstract}
Contact theories suggest that living in an ethnically mixed environment leads to a higher tolerance towards minorities, while ethnic threat theories show the least threat, in environments with only a small rate of minorities. Adolescents segregate based on many characteristics, they like some and dislike others based on popularity, wealth, coolness, attitudes toward sports or learning, etc. In order to find the impact of ethnicity, we are comparing the changes in the friendship network observed in three secondary classes in Hungary: an extreme minority, an ethnically balanced class and an ethnically homogenous class. The presented case studies, show differences among classrooms regarding the friendship ties and network structures as well. These differences suggest that the ethnic composition of classes correlate with friendship ties, yet whether these observed differences are due to ethnicity, requires a methodology that controls all other variables except ethnicity, allowing for a truly objective control group.
\end{abstract}

Keywords: Segregation, ethnicity, adolescents, friendship, network evolution

\section{Index}

1 This paper is part of a larger research supported by a Hungarian Academy of Sciences postdoctoral scholarship and has its continuation with Spanish data collection in order to validate a newly developed methodology measuring ethnic segregation. 
1. Introduction

2. Theoretical frame

3. Methodology, data and hypothesis
4. Results

5. Conclusions

6. Appendix

7. References

\section{Introduction.}

The segregative character of a society is often studied through the transformation of a population as reflected in the composition of the school classes. Research shows that cross-ethnic relations correlate with better school experience, and peer acceptance leads to a sense of belongingness (Lubbers, 2003), to a higher motivation for success (Winfield et al, 1998) and to a lower dropout rate (Hyme et al, 1996). While desegregation is shown to be beneficial not just for minority but majority children as well (Pettigrew, 2004) and one of the goals of most education policies in western societies is desegregation, in Hungary since the 80 's the segregation of Roma students more than doubled in the urban areas (Kertesi and Kézdi, 2013).

The widening ethnic gap, between Roma and non-Roma in Hungary, is present on the level of unemployment (Janky, 2006 Kézdi and Kertesi, 2011, Szalai and Zentai 2014, Messing and Bereményi, 2016), dropout rate and test scores in education (Kertesi and Kézdi, 2005), health and access to healthcare (Kézdi and Kertesi, 2011), etc.

\section{Theoretical frame}

Our theoretical frame is given by the intergroup contact theory (Allport, 1954, Pettigrow 1998, Wright et al, 1997) the social identity development theory (Tajfel \& Turner, 1979) and the intergroup threat theory (Stephan and Stephan, 2000, Riek, Mania and Gaertner, 2006, Stephan, Ybarra \& Morrison, 2009).

Research shows an inverse relationship between intergroup contact and prejudice, and Allport's conditions ${ }^{2}$ should be seen more as facilitators of positive contact outcomes rather than necessary conditions (Pettigrew and Tropp, 2006). In a later meta-analysis Pettigrew and Tropp (2008) found that while all three most frequent mediators have a significant effect on reducing prejudice, it is the anxiety reduction and empathy that yields a stronger mediation effect. Jackman and Crane (1986) found that contact with out-group members of lower status leads to negative effects, but the impact of status similarity shows disparity in the literature. Mullen et al (1992) in their meta-analysis observe a difference in the importance of equal status depending on whether the observation was conducted on laboratory groups or on real groups during field research.

According to the social identity development theory, ethnic prejudice developed along 4 subsequent phases: undifferentiated, ethnic awareness, ethnic preference and ethnic prejudice (Nesdale, 2004) the last phase occurring

\footnotetext{
${ }^{2}$ According to Allport in order for an intergroup contact to have beneficial effects four conditions need to be present: equal status, common goal, intergroup cooperation and the support of authorities, law or custom.
} 
typically at the age of 6 or 7 (Wilson and Rodkin, 2013). Measures of integration and segregation can be observed by the same-ethnicity preference and respectively by the cross-ethnicity dislike. Research shows that children adolescents even more so - prefer friends of the same-ethnicity (Graham, Taylor and Ho, 2009; Aboud, Mendelson and Purdy, 2003; Graham and Juvonen, 2002). Friendship and ethnicity, minority and majority peer relations are highly influenced by self-declared and peer/perception based ethnicity: the majority is likely to dislike the minority (regardless of the perceived minorities self-declared ethnic belongingness) and the minority tends to like those members of their community who declares themselves as belonging to the minority (Boda and Néray, 2015). In-group preference or homophily based on different social dimensions was observed in the question of foreign friendship ties (McPherson et al., 2001; Moody, 2001, Turner, 1975; Tajfel and Turner, 1979; Turner and Reynolds, 2001).

In the first presentation of the intergroup threat theory - named as integrated threat theory, Stephan and Stephan, 2000 - four threats ${ }^{3}$ were differentiated with a focus on realistic ${ }^{4}$ and symbolic ${ }^{5}$ threats (Stephan et al., 2009; Stephan, Renfro, \& Davis, 2008; Stephan \& Stephan, 1985). Research accounts both negative (Riek, Mania, \& Gaertner, 2006; Stephan, Renfro, Esses, Stephan, \& Martin, 2005) and positive (Li and Zhao, 2012; Sawires \& Peacock, 2000) effects of intergroup threat on social attitudes and behaviour.

Relying on Blau's (1977) observation of preference for individuals from own group, research shows different empirical manifestations of segregation among adolescents; aggression is often used to strengthen the in-group status (Faris and Ennett, 2012, Faris, 2012), bullying heated by ethnic differences can target both minority and majority students (Tolsma et al, 2013), social exclusion is often based on cultural and social differences (Hartup 1993; Kandel 1978; Shrum et al. 1988; McPherson et al. 2001), friendship ties are often formed along racial homophilia (Kandel, 1978; Smith 1999; Quillian and Campbell 2003; Charles 2003; Frankenberg and Lee, 2002). Extracurricular activities (Moddy, 2001), the opportunity to interact (Johnson \& Marini, 2000) are also important factors of friendship tie formation.

\section{Methodology, data and hypothesis}

By comparing the segregation changes observed in ethnically mixed classes to an ethnically homogenous class, we suggest new insights to the highly investigated area of minority integration/segregation (Laurence 2012, Cartwright, Sik and Svensson 2008; Junger-Tas, 2001; Uslaner 2010; Logan, Stults and Farley 2004, etc.)

The analysis is based on a sample from a Hungarian four-wave longitudinal panel study ${ }^{6}$ conducted between 2010 and 2013, in 44 classes of 7 secondary schools

\footnotetext{
${ }^{3}$ Realistic and symbolic threats, intergroup anxiety, negative stereotyping

${ }^{4}$ Threats to the in-group's political, economic power and resources

${ }^{5}$ The threats of in-group's beliefs, identity, etc.

6 OTKA K81336: 'Wired into Each Other: Network Dynamics of Adolescents in the Light of Status Competition, School Performance, Exclusion and Integration'. In this study, students filled out a
} 
(vocational schools, secondary technical schools and secondary grammar schools) with 1439 students. During the first wave of data collection, students were enrolled in the 9th grade.

Based on the social identity development theory, at the secondary school age we can examine both positive and negative aspects of cross-ethnic relations. Considering friendship a reliable indicator of integration (and lack of segregation), we focus our attention on friendship ties within the classroom, and the change of friendship over the 4 years of being classmates. In order to understand the impact of ethnicity (minority/majority status) on friendship tie forming patterns, 3 classes -a total of 81 students - with different ethnic composition were selected from the same school, from a county with one of the highest Roma minority from Hungary.

Relying on the intergroup contact theory, the hypothesis of the article is that with every year the level of ethnic segregation decreases and the importance of ethnic, cultural differences, as children learn more about each other.

\section{Results}

Adolescents naturally segregate based on taste, fashion, popularity, attitudes towards learning, sports, drugs, etc., basically along any and every category that can influence the life of a 14-18 year old. In order to understand what role ethnicity plays in segregation we have selected a class with only couple of Roma students, one ethnically mixed/balanced class and an ethnically homogenous (only Hungarian students). The ethnically homogenous group is aimed to show how friendships change throughout the years of secondary school regardless of the minority/majority dimension.

Classroom selection was screened on whether the class itself was participating in all four waves and if the students of the class where in that class in all four waves. For this second criteria $50 \%$ was set as a minimum criteria, in order to ensure that there isn't a too big of a change within the classroom composition. Under "class" further on we understand those students of the formal class, who were in that class and participated in all four data collections.

In analyzing the classes and the development of the friendship networks, first we will present the basic demographics that characterize the students of the class, followed by the yearly friendship networks. A comparison of the three classes will conclude the chapter.

\section{Class A. - extreme Roma minority}

The class has a great majority of girls $(76.7 \%)$, and in their primary school most of the students $(53.3 \%)$ were having good grades while $33.3 \%$ was in the top of their class. They still consider learning important, $90 \%$ said that they are content with themselves when they receive good grades and only $10 \%$ said that grades have nothing to do with their self-evaluation. The parents of $43.3 \%$ are themselves content with the grades of the child, while for $50 \%$ only partially content. $73.3 \%$ plans to continue their studies at university level. The majority of students have parents with secondary school degree (fathers $76.6 \%$ and mothers in $60.3 \%$ ). Unemployment of parents is very atypical, only 2 students had their

self-administered paper questionnaire during regular school lessons. Teacher questionnaires focusing on the classes were also administered by research assistants. 
father unemployed for at least 3 months during the previous school year and only 6 had their mother unemployed.

The four friendship networks of the secondary classes show two striking observations, one that the seemingly dense network in the first year - when they don't know each other yet - is breaking up to groups and cliques and second, that the last year is characterized by several friendship triangles.

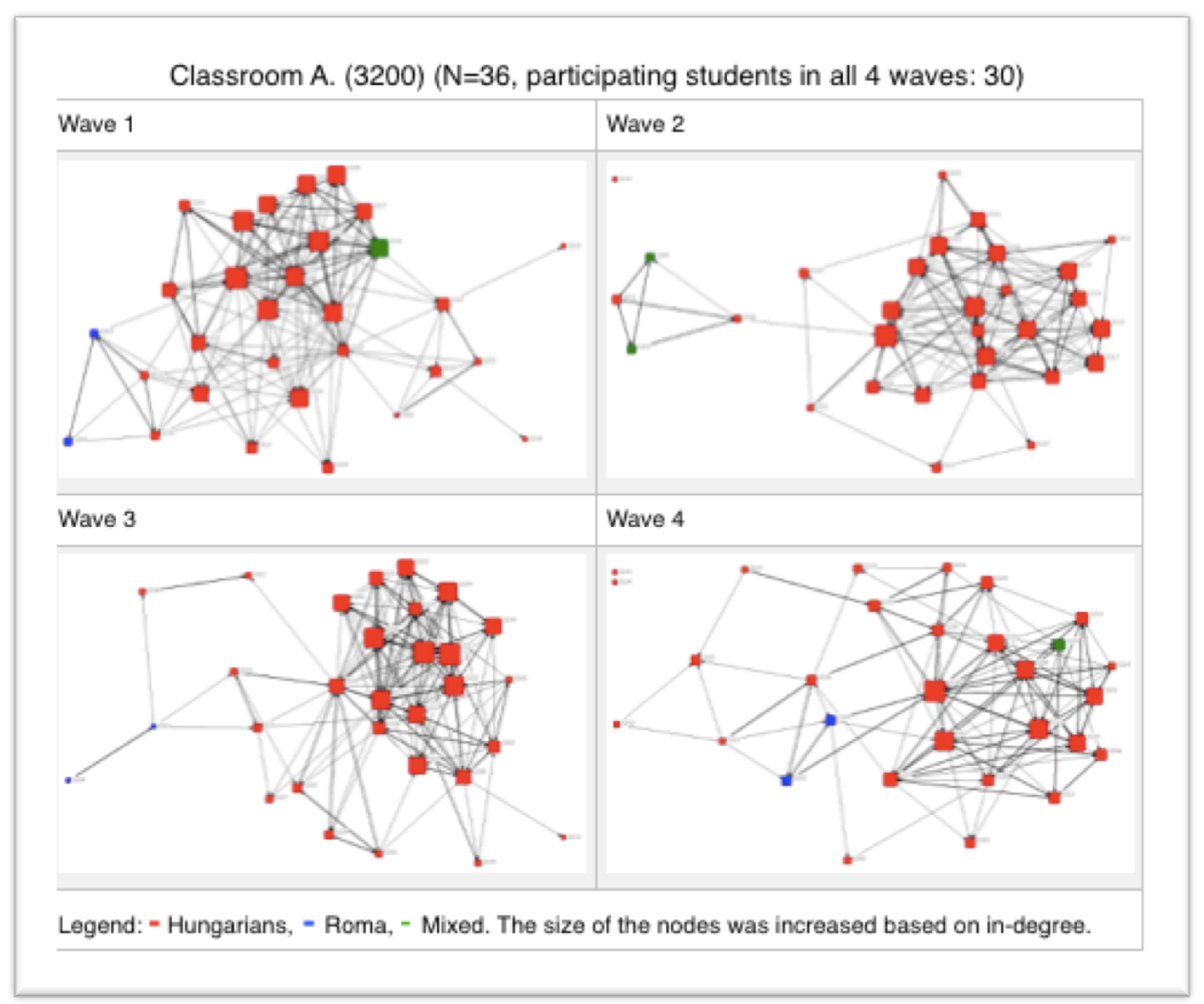

Image 1. Class A. Friendship networks

Image 2 shows the uneven distribution by ethnicity. Both out-degree and indegree shows, that ethnicity correlates with the number of friendship ties. The black line stand for the class average throughout the years. There was only one student with declared mixed identity, and both highest out- and in-degree (much higher than the class average) belong to this one student. 

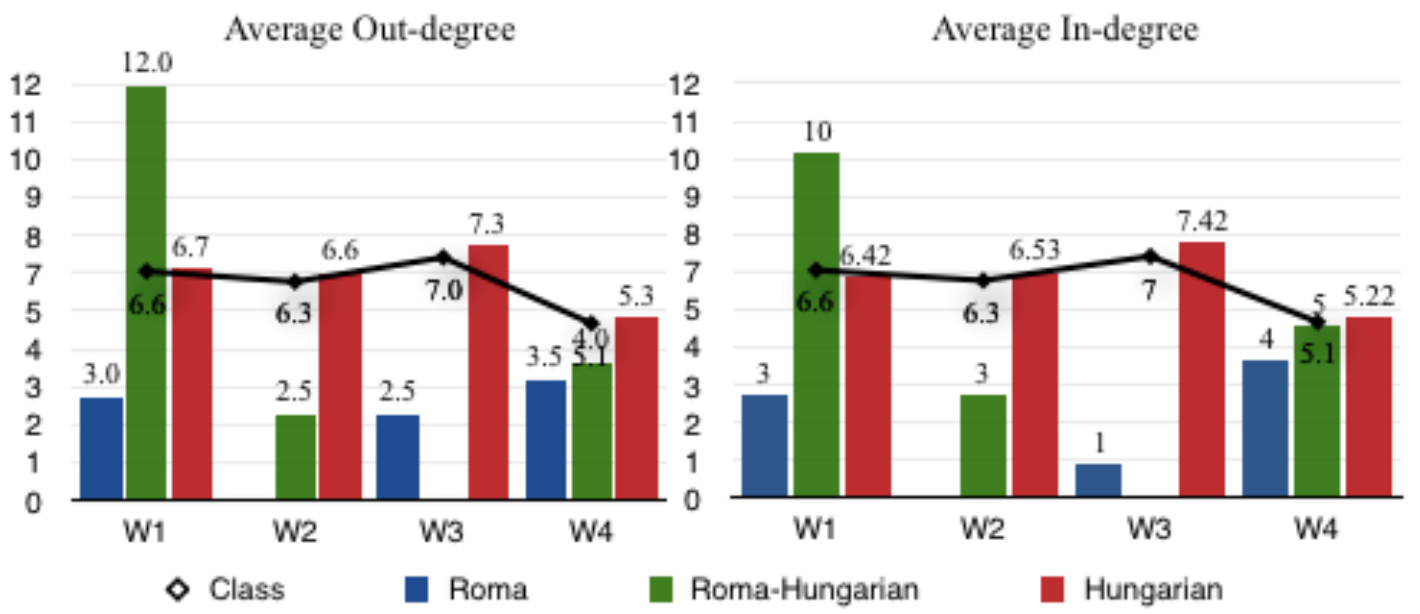

Image 2. Class A. Out-degree and in-degree by self-declared ethnicity

Roma $(\mathrm{N}=2)$ have on average 3 ties (both nominations from and to them) while Hungarians have 6 to 7 . The number of friends is changing along the years, and so does ethnic self-declaration. The two Roma students declared themselves Roma and Hungarian in wave 2, only to declare themselves Roma again in wave 3 and 4 . The student who was saying ethnically mixed in wave 1 , declared himself Hungarian in wave 2 and 3 and didn't answer the question in wave 4, as such we considered him as Roma\&Hungarian. Hungarians are characterized with a slightly increasing friendship network, both based on out-degree and in-degree. This tendency only decreases in the last wave. Roma students have most connections in the last school year, suggesting that integration - to a certain degree - might occur by the end of the school, yet on average they still have at least one less friend than a Hungarians. The higher in-degrees, and the shift of identity of both Roma and Roma\&Hungarians shows, that Hungarian students are more popular, than their minority classmates. The friendship nomination between the two Roma students lasts through the years, while the RomaHungarian student has no connection with the Roma kids. The third wave is the least dense and by the fourth wave the number of ties drastically decreases, first of all due to the breaking up of friendships among Hungarians.

\begin{tabular}{|c|c|c|c|c|c|}
\hline \multirow{2}{*}{\multicolumn{2}{|c|}{ Respondent }} & \multicolumn{3}{|c|}{ Friend } & \multirow{3}{*}{$\begin{array}{r}\text { Total } \\
6\end{array}$} \\
\hline & & Roma & Roma\&Hungarian & Hungarian & \\
\hline \multirow{4}{*}{1} & Roma & 2 & 0 & 4 & \\
\hline & Roma-Hungarian & 0 & 0 & 12 & 12 \\
\hline & Hungarian & 4 & 10 & 166 & 180 \\
\hline & Total & 6 & 10 & 182 & 198 \\
\hline \multirow{4}{*}{2} & Roma & NA & NA & NA & 0 \\
\hline & Roma-Hungarian & NA & 2 & 3 & 5 \\
\hline & Hungarian & NA & 4 & 178 & 182 \\
\hline & Total & 0 & 6 & 181 & 187 \\
\hline \multirow{4}{*}{3} & Roma & 2 & NA & 3 & 5 \\
\hline & Roma-Hungarian & NA & NA & NA & 0 \\
\hline & Hungarian & 0 & NA & 205 & 205 \\
\hline & Total & 2 & 0 & 208 & 210 \\
\hline \multirow{4}{*}{4} & Roma & 2 & $0^{*}$ & 5 & 7 \\
\hline & Roma-Hungarian & 0 & 0 & 4 & 0 \\
\hline & Hungarian & 6 & 5 & 134 & 140 \\
\hline & Total & 8 & 0 & 139 & 147 \\
\hline
\end{tabular}

Table 1. Class A - Distribution of cross-ethnic and same-ethnic ties 


\section{Class B. - ethnically mixed}

Nearly half of the students in the second classroom are Roma and half nonRoma; as such the term of "minority" has less of a strict meaning. Similarly to class A, class $\mathrm{B}$ also has a majority of girls $(88.9 \%)$, with most being average students in their primary school. (55.6\%) were having good grades, while $33.3 \%$ was in the top of their class. Good grades are non-the less important, $72.2 \%$ is content with themselves when they receive good grades, and for $11.1 \%$ selfevaluation has nothing to do with grades. Half of the students think that their parents are partially content with their grades, while 16.7 thinks that their parents are content with their grades. Only $33.3 \%$ plans to continue their education at university level. A third of the respondents have parents with 8 classes or less, and another third of the parents have vocational education. Unemployment also shows a worse case than in the case of parents from Class $A, 11.1 \%$ of the fathers and $33.3 \%$ of the mothers was unemployed for at least 3 months during the previous school year.

The friendship network throughout the four secondary school years is presented in the following image, and once again the third year is different from the others. In the third year the separation of Roma and non/Roma students is the most obvious, only to be semi balanced in the fourth year.

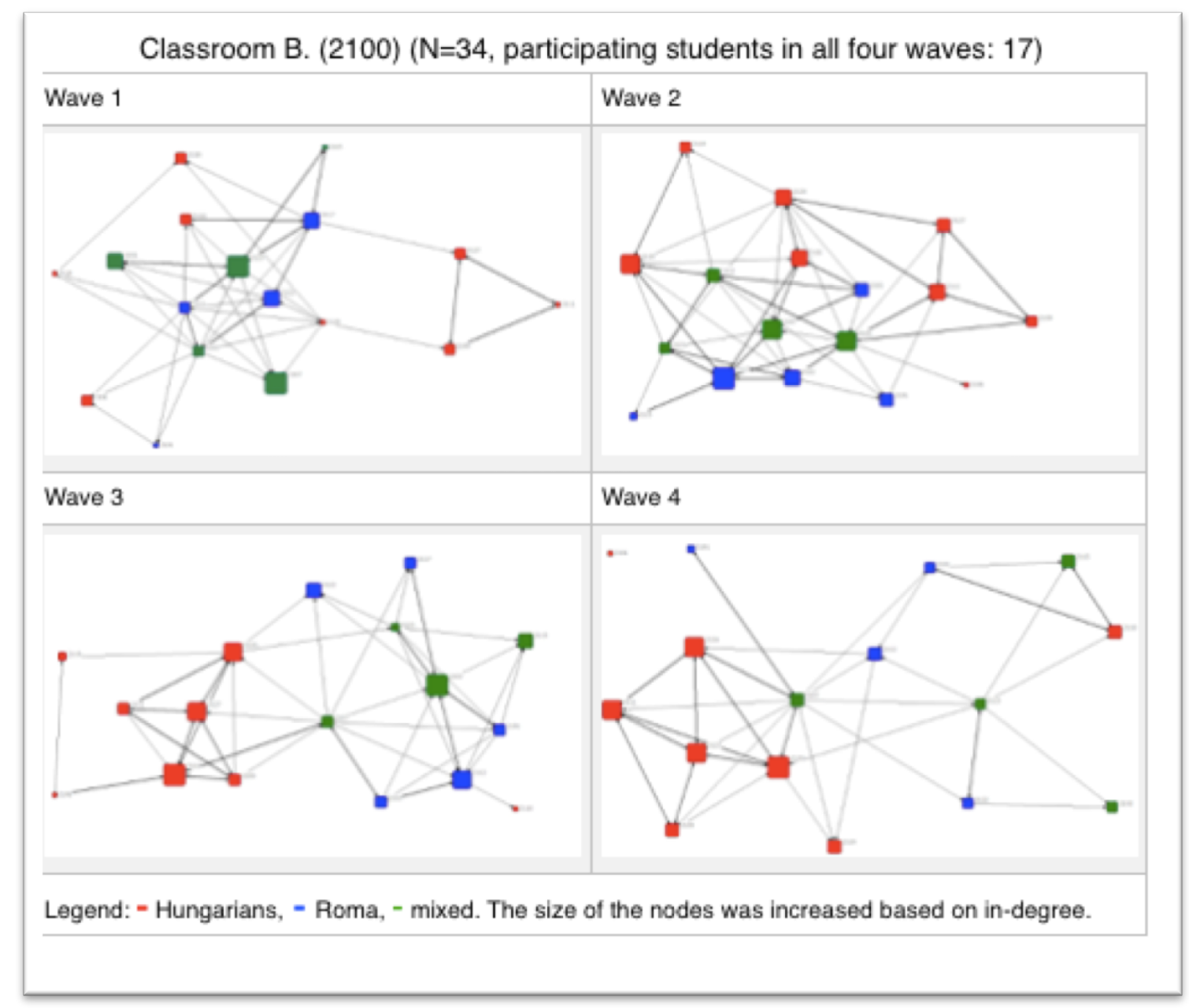


Tie distribution once again shows that students of different ethnic background tend to form friendship ties in different ways. Students with mixed ethnic backgrounds are on average sending and receiving the most ties, while Hungarians have the least number of friends. Roma students have the largest difference between the number of friendship ties sent and received, suggesting that their friendship is not always reciprocated. The opposite is true on average for Hungarians, their in-degree is higher than their out-degree, suggesting that they are seen as popular, "good to be friend with".

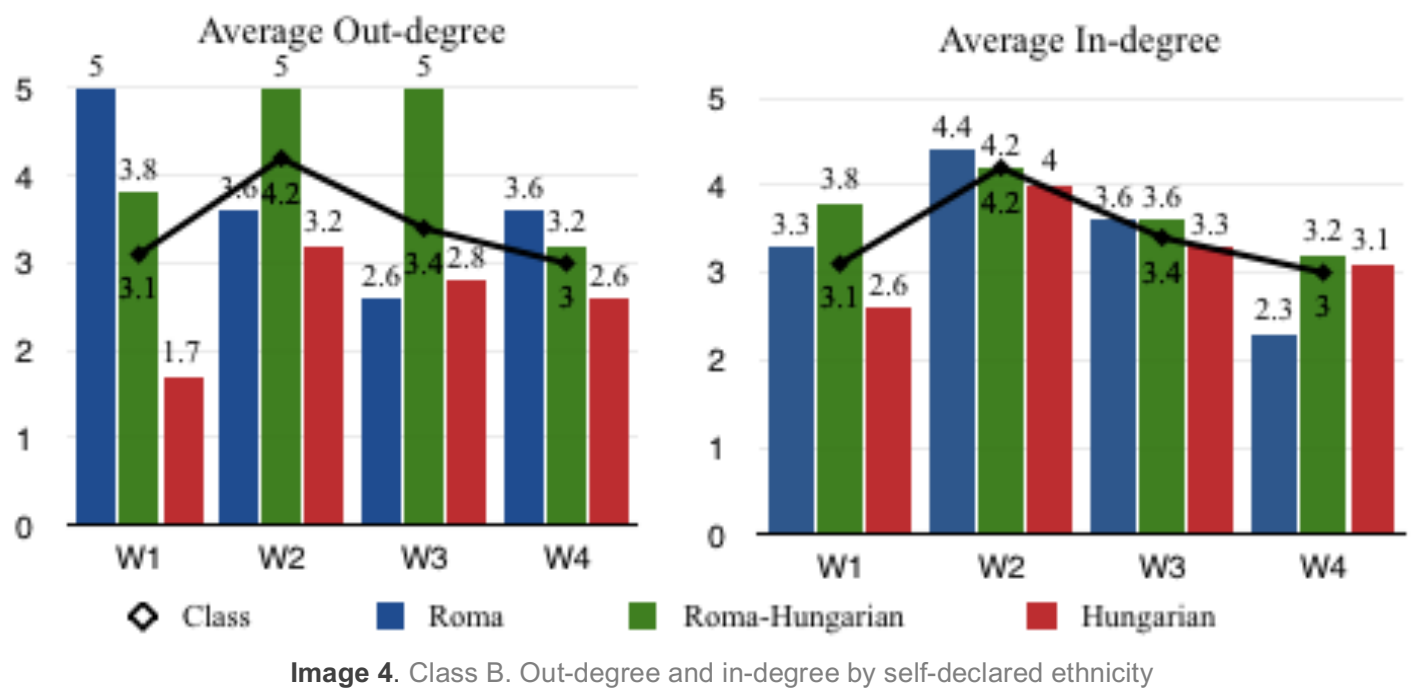

The change of number of cross-ethnic and same-ethnic ties doesn't show any ethnic characteristic in this mixed class.

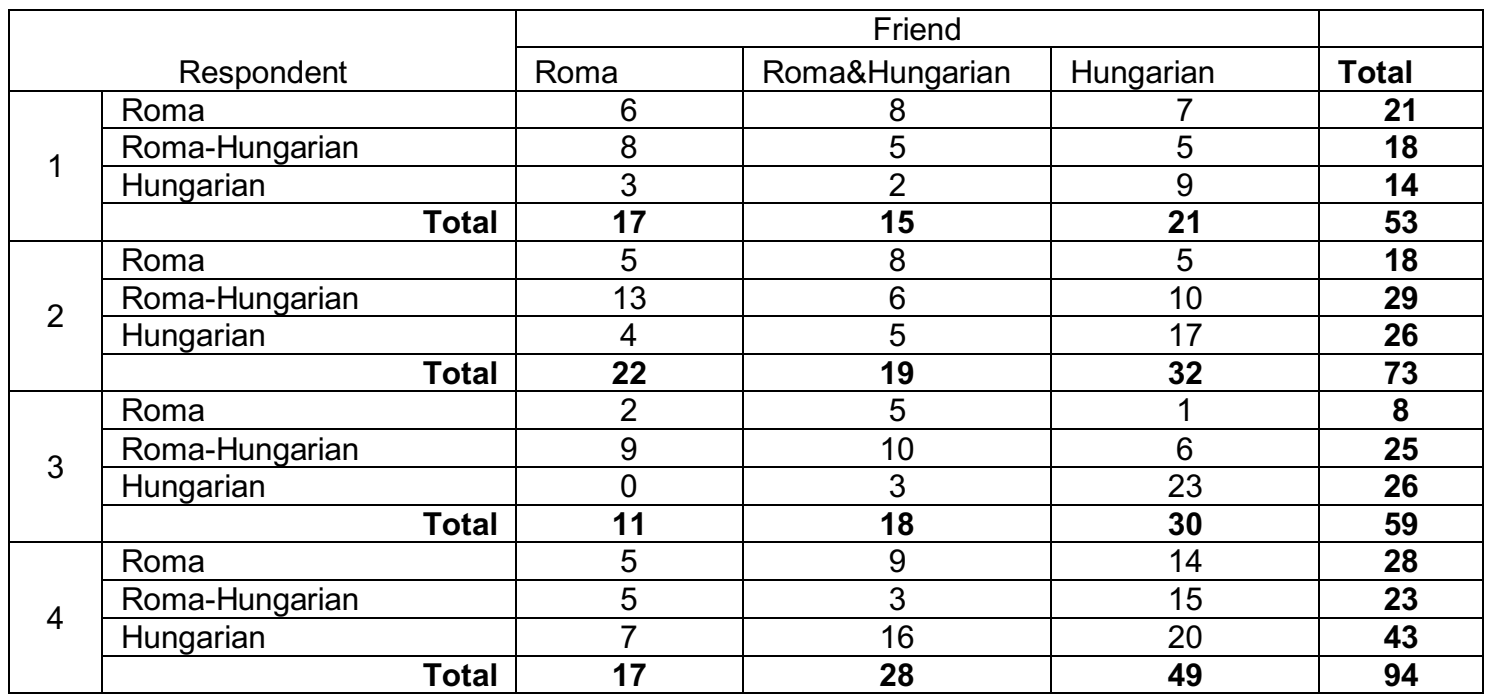

Table 2. Class B - Distribution of cross-ethnic and same-ethnic ties

\section{Class C. - ethnically homogeneous}

With only Hungarian students, the third class serves as a baseline, compared to which ethnicity based segregation and the changes within friendship networks can be measured. 
With $78.7 \%$, class C. is also a majority girl class, where $54.5 \%$ of the students were among the top students in their primary school and only $9.1 \%$ said that they had average grades. For $81.8 \%$ of the students, grade is important while for $18.2 \%$ grades have no influence on their self-evaluation. The majority of students think that their parents are content $(36.4 \%)$ or partially content $(45.5 \%)$ with their grades. $78.7 \%$ of the students plan to continue their studies at university level. The majority of fathers $(36.4 \%)$ once again has only vocational training, but the proportion of fathers who do have college $(27.3 \%)$ and university $(18.2 \%)$ degree is higher than in the case of Class $A$ and $B$. One third of the mothers also graduated from college. Unemployment is even less typical, with only one father being unemployed for at least 3 months during the previous school year.

Classroom C. (1300) ( $\mathrm{N}=37$, participating students in all 4 waves: 33$)$

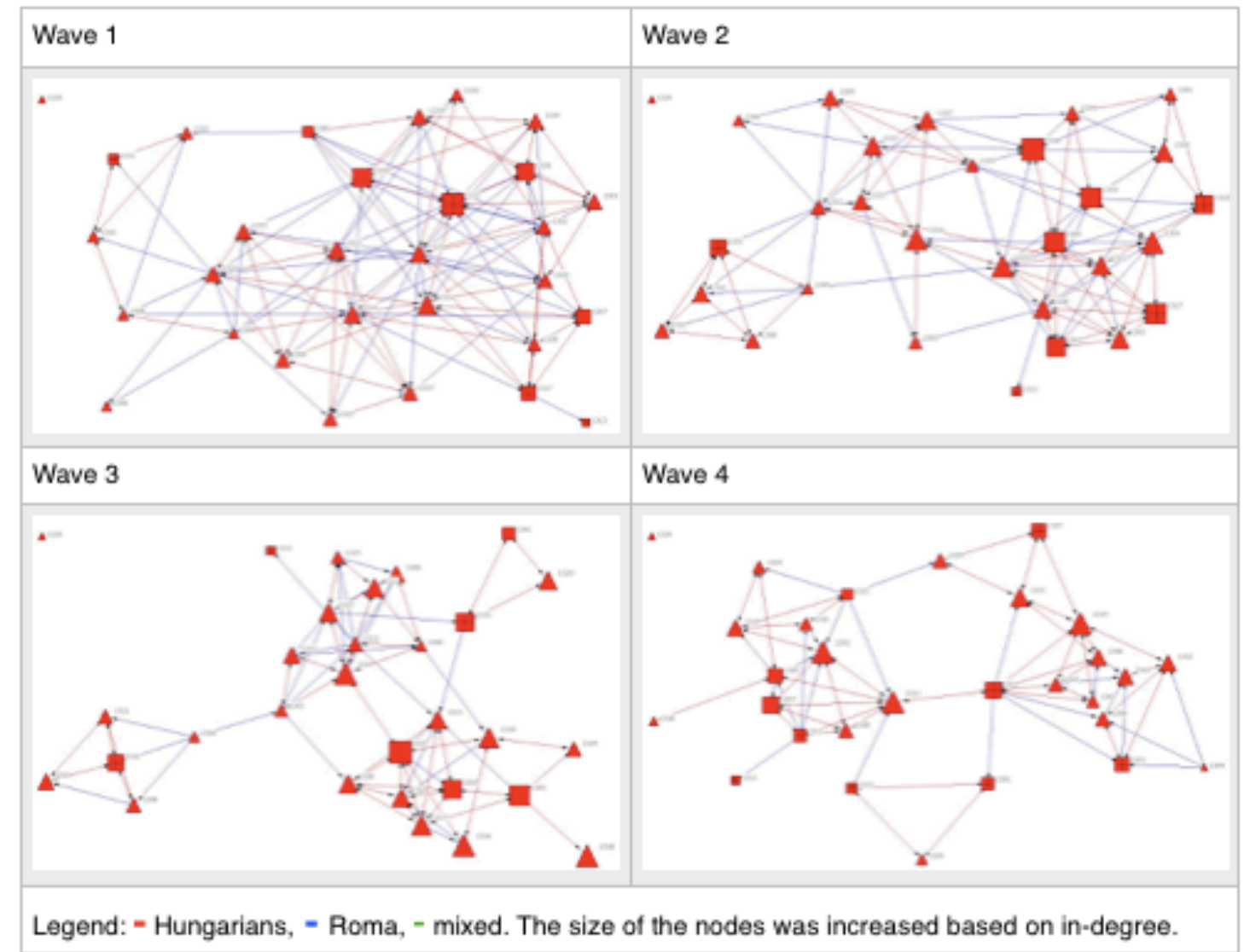

Image 5. Class C. Friendship networks

\begin{tabular}{|l|l|l|l|l|}
\hline & $\begin{array}{l}\text { Network Centralization } \\
\text { (Outdegree) }\end{array}$ & $\begin{array}{l}\text { Network Centralization } \\
\text { (Indegree) }\end{array}$ & Average Out-Degree & Average In-degree \\
\hline 1 & $54,70 \%$ & $22,59 \%$ & $5.667(4.085)$ & $5.667(2.662)$ \\
\hline 2 & $21,28 \%$ & $10,58 \%$ & $5.033(2.949)$ & $5.033(2.089)$ \\
\hline 3 & $18,19 \%$ & $11,06 \%$ & $3.900(2.226)$ & $3.900(2.039)$ \\
\hline 4 & $21,76 \%$ & $14,63 \%$ & $3.900(2.211)$ & $3.900(2.071)$ \\
\hline
\end{tabular}

Table 1. Class C. Distribution of in degree and out-degree

In this class the friendship ties - both out-degree and in-degree - show a decreasing trend, having most friends in the first year, stabilizing in the third. The average number of friends in the last two years is 3.9 . 


\section{Conclusions}

The class comparison along the changes in friendship ties, not surprisingly show that Class A (with only 2 Roma students) is very similar to Class C (with only Hungarian students). Both classes are characterized with a decreasing trend of number of ties, decreasing density and increasing reciprocity. While the decrease of density and of number of ties suggests that less classmates are being named as friends, the increasing reciprocity argues for the strengthening/solidification of friendships. In the class $A$, the third year is off trend on all these indicators, but the trend itself is very similar to the ethnically homogenous class. Class $B$ has a density that remains around 0.2 , which is higher than the density measured in the ethnically homogenous class and close to the ones measured in Class A with two minority students. The reciprocity in Class $B$ also lacks the increasing trend observed in the other two classes, and except the second year - which is characterized with the most ties, and highest density and reciprocity as well typically lower than in the other classes. The percentage of all ordered triples is above $50 \%$, in most years for all classes, around half or the relations that could easily be transitive, actually are. Lowest percentages can be observed in the class with more minority students.

\begin{tabular}{|l|l|l|l|l|l|}
\hline \multicolumn{2}{|c}{} & No of Ties & Density & Reciprocity & $\begin{array}{l}\text { Transitivity: \% of ordered triples in } \\
\text { which i-->j and j-->k that are transitive }\end{array}$ \\
\hline \multirow{4}{*}{ A } & 1 & 198 & 0,2276 & 0,3944 & 61.45 \\
\cline { 2 - 6 } & 2 & 189 & 0,2172 & 0,4882 & 54.88 \\
\cline { 2 - 6 } & 3 & 210 & 0,2414 & 0,4483 & 62.35 \\
\cline { 2 - 6 } & 4 & 154 & 0,177 & 0,5098 & 51.86 \\
\hline \multirow{4}{*}{ B } & 1 & 53 & 0,1949 & 0,2927 & 40.27 \\
\cline { 2 - 6 } & 2 & 73 & 0,2684 & 0,5208 & 39.02 \\
\cline { 2 - 6 } & 3 & 59 & 0,2169 & 0,3721 & 51.53 \\
\hline \multirow{4}{*}{ C } & 4 & 48 & 0,2 & 0,4118 & 54.23 \\
\cline { 2 - 6 } & 1 & 170 & 0,1954 & 0,5179 & 46.75 \\
\cline { 2 - 6 } & 2 & 151 & 0,1736 & 0,5253 & 53.72 \\
\cline { 2 - 6 } & 3 & 117 & 0,1345 & 0,5811 & 55.97 \\
\hline
\end{tabular}

Table 3. Descriptive network statistics

The clicks that have a minimum of 3 actors where observed along ethnic composition, the most striking observation being that by year 3 in Class B - with several Roma as well as Roma\&Hungarian students - there are no clicks that have at least one Roma student.

\begin{tabular}{|c|c|c|c|c|c|c|}
\hline & & Total & at least 1 Roma & $\begin{array}{ll}\text { at least } 1 \text { Roma- } \\
\text { Hungarian }\end{array}$ & $\begin{array}{l}\text { Only } \\
\text { Hungarians }\end{array}$ & no Hungarians \\
\hline \multirow{4}{*}{$A$} & 1 & 13 & 1 & 6 & 6 & 0 \\
\hline & 2 & 23 & NA & 2 & 21 & 0 \\
\hline & 3 & 21 & 0 & NA & 21 & 0 \\
\hline & 4 & 13 & 1 & 1 & 11 & 0 \\
\hline \multirow{4}{*}{ B } & 1 & 2 & 1 & 1 & 1 & 1 \\
\hline & 2 & 7 & 4 & 4 & 2 & 2 \\
\hline & 3 & 4 & 0 & 0 & 4 & 0 \\
\hline & 4 & 3 & 0 & 1 & 2 & 0 \\
\hline \multirow{4}{*}{ C } & 1 & 15 & NA & NA & 15 & NA \\
\hline & 2 & 9 & NA & NA & 9 & NA \\
\hline & 3 & 14 & NA & $\mathrm{NA}$ & 14 & $\mathrm{NA}$ \\
\hline & 4 & 10 & NA & NA & 10 & NA \\
\hline
\end{tabular}


The presented case studies, allow us to observe differences among classrooms. These differences suggest that the ethnic composition of classes correlate with friendship ties observed among classmates throughout the entire 4 years of secondary school. Having Class B different from Class A (extreme minority) and Class $C$ (ethnically homogenous) would suggest that ethnicity even after 4 years of being classmates not necessarily bring students of different ethnicities together. Whether the observed differences are truly due to the ethnicity of students, more specifically if there is an ethnic discrimination - positive or negative - when it comes to friendship ties among adolescents, requires a methodology that controls all other variables except ethnicity. This allows us to have a proper control group that is truly objective. The control group must be as similar to the network to which we wish to analyse, yet differing only in the ethnic variable which we wish to inquire about. This research is part of an ongoing project in which we are developing a control group approach that uses ERGM in order to mathematically create the optimal control group for comparison to your observed.

\section{References}

Aboud, F. E., Mendelson, M. J., \& Purdy, K. T. (2003). Cross-race peer relations and friendship quality. Inter- national Journal of Behavioral Development, 27, 165-173.

Allport GW. (1954). The Nature of Prejudice. Reading, MA: Addison-Wesley. 537 pp.

Anderson LS. 1995. Outdoor adventure recreation and social integration: a social- psychological perspective. PhD thesis. Univ. Minn., Minneapolis, MN. 271 pp.

Blau, P. (1977). Inequality and Heterogeneity. New York: Free Press.

Boda, Zs. \& Néray, B. (2015) Inter-ethnic friendship and negative ties in secondary school, Social Networks 43 (2015) 57-72, doi: http://dx.doi.org/10.1016/j.socnet.2015.03.004

Cartwright, A., Sik E., Svensson, S., (2008). Social Capital and the integration of Minorities and immigrants in Hungary, Working paper, CEU, Budapest

Charles, C. Z. 2000. "Residential Segregation in Los Angeles." Pp. 167-220 in Prismatic Metropolis: Inequality in Los Angeles, edited by L. Bobo, M. L. Oliver, J. H. Johnson, Jr., and A. Valenzuela, Jr. New York: Russell Sage.

Cutler, D., E. Glaeser, and J. Vigdor. (1999). "The Rise and Decline of the American Ghetto." Journal of Political Economy 107:455-506.

Eskilson A. 1995. Trends in homophobia and gender attitudes: 1987-1993. Presented at Annu. Meet. Am. Sociol. Assoc., 90th, Washington, DC

Faris, R., 2012. Aggression, exclusivity, and status attainment in interpersonal networks. Soc. Forces 90 (4), 1207-1235. http://dx.doi.org/10.1093/sf/sos074

Faris, R. \& Ennett, S. (2012). Adolescent aggression: the role of peer group status motives, peer aggression, and group characteristics. Soc. Newt. 34 (4), 371-378, http://dx.doi.org/10.1016/j.socnet.2010.06.003 
Farley R., and W. H. Frey. (1994). "Changes in the Segregation of Whites from Blacks during the 1980s: Small Steps toward a More Integrated Society." American Sociological Review 59:23-45.

Frankenberg, Erica, and Chungmei Lee. 2002. "Race in American Public Schools: Rapidly Resegregating School Districts." Cambridge, Mass.: Harvard Civil Rights Project. http://www.civilrightsproject.harvard.edu/research/deseg/reseg_schools02.php

Glaeser, E., and J. Vigdor. 2001. Racial Segregation in the 2000 Census: Promising News. Washington, D.C.: Brookings Institution.

Graham, S., Taylor, A. Z., \& Ho, A. Y. (2009). Race and ethnicity in peer relations research. In K. H. Rubin, W. M. Bukowski, \& B. Laursen (Eds.), Handbook of peer interactions, relationships, and groups (pp. 394-413). New York: Guilford.

Graham, S., \& Juvonen, J. (2002). Ethnicity, peer harassment, and adjustment in middle school: An exploratory study. Journal of Early Adolescence, 22, 173-199.

Hartup, W.W., 1993. Adolescents and their friends. New Dir. Child Adoles. Dev. 1993 (60), 3-22.

Herek GM, Capitanio JP. 1996. "Some of my best friends": intergroup contact, conceal- able stigma, and heterosexuals' attitudes toward gay men and lesbians. Pers. Soc. Psychol. Bull. 22:412-24

Hymel, S., Comfort, C., Schonert-Reichl, K., McDougall, P., 1996. Academic failure and school dropout: the influence of peers. Cambridge Stud. Soc. Emot. Dev., 313-345.

Jackman MR \& Crane M. (1986). "Some of my best friends are black...": interracial friendship and whites' racial attitudes. Public Opin. Q. 50:459-86

Janky, B., 2006. The social position and fertility of Roma women. In: Nagy, I., Pongracz, M., Toth, I.G. (Eds.), Changing Roles: Report on the Situation of Women and Men in Hungary 2005. TÁRKI Social Research Institute, Budapest, pp. 132-145.

Junger-Tas, J., (2001). Ethnic Minorities, Social Integration and Crime, European Journal on Criminal Policy and Research, 9, 1:5-29

Kandel, D. B. (1978). Homophily, selection, and socialization in adolescent friendships. American Journal of Sociology, 84, 427-436. http://dx.doi.org/10.1086/226792

Kawabata, Y., \& Crick, N. R. (2008). The role of cross- racial/ethnic friendships in social adjustment. Developmental Psychology, 44, 1177-1183.

Kertesi, G. \& Kezdi, G. (2005). Roma children in the transformational recession - widening ethnic schooling gap and Roma poverty in post-communist Hungary. In: Budapest Working Papers on the Labour Market No. 0508, Institute of Economics, Centre for Economic and Regional Studies, Hungarian Academy of Sciences http://ideas.repec.org/p/has/bworkp/0508.html

Kertesi, G., Kézdi, G., 2011. Roma employment in Hungary after the postcommunist transition1. Economics of Transition 19 (3), 563-610. http://dx.doi.org/10.1111/j.1468-0351.2011.00410.x

Kertesi, G. and Kézdi G., 2013."Ethnic Segregation between Hungarian Schools: 
Longrun Trends and Geographic Distribution." Hungarian Statistical Review. Special number 16.

Kertesi, G. and Kézdi G., 2016. School segregation. School Choice, and Educational Policies in 100 Hungarian Towns, Roma Educational Fund, Budapest, 2013. pp. 1-145.

Kézdi, G., Kertesi, G., 2011. The Roma/non-Roma test score gap in Hungary. Am. Econ. Rev. 101 (3), 519-525. http://dx.doi.org/10.1257/aer.101.3.519

Kindermann, T. A., \& Gest, S. D. (2009). Assessment of the peer group: Identifying naturally occurring social networks and capturing their effects. In K. H. Rubin, W. M. Bukowski, \& B. Laursen (Eds.), Handbook of peer interactions, relationships, and groups (pp. 100-117). New York: Guilford.

Laurence, J. (2012). The Emancipation of Europe's Muslims: The State's Role in Minority Integration. Princeton and Oxford: Princeton University Press, http://dx.doi.org/10.1515/9781400840373

Lease, A. M., \& Blake, J. J. (2005). A comparison of majority race children with and without a minority-race friend. Social Development, 14, 20-41. http://dx.doi.org/10.1111/j.1467-9507.2005.00289.x

Li, T. and Zhao, Y (2012) Help Less or Help More -Perceived Intergroup Threat and Out-Group Helping, International Journal of Psychological Studies; Vol. 4, No. 4; 2012, http://dx.doi.org/10.5539/ijps.v4n4p90

Logan, J.R, Stults, B.J. and Farley, R., (2004). Segregation of Minorities in the Metropolis: Two Decades of Change. Demography 41.1: 1-22.

Lubbers, M.J., 2003. Group composition and network structure in school classes: a multilevel application of the $p^{*}$ model. Soc. Netw. 25 (4), 309-332., http://dx.doi.org/10.1016/s0378-8733(03)00013-3

Martin, J. L. (2009). Formation and Stabilization of Vertical Hierarchies among Adolescents: Towards a Quantitative Ethology of Dominance among Human. Social Psychology Quarterly, 241-64., http://dx.doi.org/10.1177/019027250907200307

Mártonfi György (manuscript) The impact of changes in Hungarian legislation on education of disadvantaged pupils and Romani children and youth, Roma Educational Fund, Budapest.

McPherson, M., Smith-Lovin, L., Cook, J.M., (2001). Birds of a feather: homophily in social networks. Annul. Rev. Sociol. 27, 415-444. http://dx.doi.org/10.1146/annurev.soc.27.1.415

Messing, V. \& Bereményi, B.Á. (2016): Is ethnicity a meaningful category of employment policies for Roma? A comparative case study of Hungary and Spain, Ethnic and Racial Studies, http://dx.doi.org/10.1080/01419870.2016.1213402

Moody, J., (2001). Race, school integration, and friendship segregation in America. Am. J. Sociol. 107 (3), 679-716. http://dx.doi.org/10.1086/338954

Moody, J., Brynildsen, W. D., Osgood, W.D., Feinberg, M.E. \&Gest, S. (2011). Popularity Trajectories and Substance Use in Early Adolescence. Social Networks, 33 (2), 101-112 http://dx.doi.org/10.1016/j.socnet.2010.10.001

Mouw, T., \& Entwisle, B. (2006). Residential segregation and interracial 
friendships in schools. American Journal of Sociology, 112, 394-441.

Mullen B, Brown R, Smith C. (1992). Ingroup bias as a function of salience, relevance, and status: an integration. Eur. J. Soc. Psychol. 22:103-22, http://dx.doi.org/10.1002/ejsp.2420220202

Moody, J. 2001. "Race, School Integration, and Friendship Segregation in America." American Journal of Sociology 107:679-716., http://dx.doi.org/10.1086/338954

Nesdale, D. (2004). Social identity processes and children's ethnic prejudice. In M. Bennett \& F. Sani (Eds.), The development of the social self (pp. 219-246). New York: Psychology Press., http://dx.doi.org/10.4324/9780203391099_chapter_8

Orfield, G. (2001). Schools more separate: Consequences of a decade of resegregation. Cambridge, MA: Harvard University Civil Rights Project.

Paolini, S., Hewstone, M., Cairns, E., \& Voci, A. (2004). Effects of direct and indirect cross-group friendships on judgments of Catholics and Protestants in Northern Ireland: The mediating role of an anxiety- reduction mechanism. Personality and Social Psychology Bulletin, 30, 770 -786. , http://dx.doi.org/10.1177/0146167203262848

Pettigrew, T. F. (1998). Intergroup Contact Theory. Annual Review of Psychology, 49:65-85, DOI: 10.1146/annurev.psych.49.1.65

Pettigrew, T. F. (2004). Justice deferred: A half century after Brown v. Board of Education. American Psychologist, 59, 521-529. http://dx.doi.org/10.1037/0003066x.59.6.521

Pettigrew, T. F., \& Tropp, L. R. (2006). A meta-analytic test of intergroup contact theory. Journal of Personality and Social Psychology, 90, 751-783., http://dx.doi.org/10.1037/0022-3514.90.5.751

Pettigrew, T. F., \& Tropp, L. R. (2008). How does intergroup contact reduce prejudice? Meta-analytic tests of three mediators. European Journal of Social Psychology. 38, 922-934 (2008), DOI: 10.1002/ejsp.504 , http://dx.doi.org/10.1002/ejsp.504

Riek, B.M., Mania, E.W., \& Gaertner, S.L. (2006). Intergroup threat and out-group attitudes: A meta-analytic review. Personality and Social Psychology Review, 10, 336-353. http://dx.doi.org/10.1207/s15327957pspr1004_4

Quillian, Lincoln, and Mary E. Campbell. 2003. "Beyond Black and White: The Present and Future of Multiracial Friendship Segregation." American Sociological Review 68:540-66. http://dx.doi.org/10.2307/1519738

Sawires, J. N., \& Peacock, M. J. (2000). Symbolic racism and voting behavior on Proposition 2091. Journal of Applied Social Psychology, 30(10), 2092-2099. http://dx.doi.org/10.1111/j.1559-1816.2000.tb02426.x

Smith, T. W. 1999. "Trendlets: Inter-racial Friendships [and] the Emerging 21st Century American Family." GSS News 13:3-4.

Stephan, W. G., \& Stephan, C. W. (1985). Intergroup anxiety. Journal of Social Issues, 41(3), 157-175. http://dx.doi.org/10.1111/j.1540-4560.1985.tb01134.x

Stephan, W. G., \& Stephan, C. W. (2000). An integrated threat theory of 
prejudice. In S. Oskamp (Ed.), Reducing prejudice and discrimination (pp. 2345). Mahwah, NJ: Erlbaum.

Stephan, W. G., Renfro, C. L, \& Davis, M. D. (2008). The role of threat in intergroup relations. In U. Wagner, L. Tropp, G. Finchilescu, \& C. Tredoux (Eds.), Improving Intergroup Relations: Building on the Legacy of Pettigrew, T.F (pp. 5572). Wiley-Blackwell. http://dx.doi.org/10.1002/9781444303117.ch5

Stephan, W. G., Renfro, C. L., Esses, V. M., Stephan, C. W., \& Martin, T. (2005). The effects of feeling threatened on attitudes toward immigrants. International $\begin{array}{llll}\text { Journal of Intercultural } \quad \text { Relations, } & \text { 29(1), }\end{array}$ http://dx.doi.org/10.1016/j.jintrel.2005.04.011

Stephan, W. G., Ybarra, O., \& Morrison, K. R. (2009). Intergroup Threat Theory. In T. D. Nelson (Ed.), Handbook of prejudice, stereotyping, and discrimination (pp. 43-59). New York: Psychology Press

Szalai, Julia, and Violetta Zentai, eds. (2014). Faces and Causes of Roma Marginalization in Local Contexts: Hungary, Romania, Serbia. CPS Books. Budapest: Central European University.

Tajfel, H. and Turner, J.C., 1979. An integrative theory of intergroup conflict. In: Austin, W.G., Worchel, S. (Eds.), The Social Psychology of Intergroup Relations. Brooks/Cole, Monterey, CA, pp. 33-47.

Tolsma, J., van Deurzen, I., Stark, T.H., Veenstra, R., 2013. Who is bullying whom in ethnically diverse primary schools? Exploring links between bullying, ethnicity, and ethnic diversity in Dutch primary schools. Soc. Netw. 35 (1), 5161, http:// dx.doi.org/10.1016/j.socnet.2012.12.002

Turner, J.C., 1975. Social comparison and social identity: some prospects for intergroup behaviour. Eur. J. Soc. Psychol. 5 (1), 1-34, http://dx.doi.org/10.1002/ejsp. 2420050102

Turner, J.C., Reynolds, K.J., 2001. The social identity perspective in intergroup relations: theories, themes, and controversies. In: Brown, R., Gardner, S.L. (Eds.), Blackwell Handbook of Social Psychology: Intergroup Processes. Blackwell Publishers Ltd., pp. 133-152. http://dx.doi.org/10.1002/9780470693421.ch7

Uslaner E.M., 2010. Segregation, mistrust and minorities, Ethnicities,10:415-434, http://dx.doi.org/10.1177/1468796810378325

Wagner U, Hewstone M, Machleit U. 1989. Contact and prejudice between Germans and Turks. Hum. Relat. 42:561-74, http://dx.doi.org/10.1177/001872678904200701

Wigfield, A., Eccles, J.S., Rodriguez, D., 1998. The development of children's motivation in school contexts. Rev. Res. Educ. 23, 73-118. http://dx.doi.org/10.3102/0091732x023001073

Wimmer, A. and Lewis K., 2010. Beyond and Below Racial Homophily: ERG Models of a Friendship Network Documented, American Journal of Scoiology, 2:583-642, http://dx.doi.org/10.1111/cdev.12020

Wilson, T. M., \& Rodkin P.C. (2013). Children's Cross-Ethnic Relationships in Elementary Schools: Concurrent and Prospective Associations Between Ethnic Segregation and Social Status. Child Development, May/June 2013, Volume 84, 
Number 3, Pages 1081-1097, http://dx.doi.org/10.1111/cdev.12020

Wright, S.C., Aron, A., McLaughlin-Volpe, T., Ropp, S.A., (1997). The extended con- tact effect: knowledge of cross-group friendships and prejudice. J. Person.

Soc. Psychol. 73 (1), 73-90, http://dx.doi.org/10.1037/0022-3514.73.1.73. 